\title{
Menthol to Induce Non-shivering Thermogenesis via TRPM8/PKA Signaling for Treatment of Obesity
}

\author{
Owen Davis Sanders ${ }^{1, *}$, Jayalekshmi Archa Rajagopal ${ }^{2}$, Lekshmy Rajagopa ${ }^{3}$ \\ ${ }^{1}$ Department of Biology, Portland State University, Portland, OR, USA; ${ }^{2}$ Department of Pathology, D.Y. Patil Medical College, Kolhapur, ${ }^{3}$ Oto-Rhino-Laryngology, \\ College of Physicians and Surgeons, Mumbai, India
}

Increasing basal energy expenditure via uncoupling protein 1 (UCP1)-dependent non-shivering thermogenesis is an attractive therapeutic strategy for treatment of obesity. Transient receptor potential melastatin 8 (TRPM8) channel activation by cold and cold mimetics induces UCP1 transcription and prevents obesity in animals, but the clinical relevance of this relationship remains incompletely understood. A review of TRPM8 channel agonism for treatment of obesity focusing on menthol was undertaken. Adipocyte TRPM8 activation results in $\mathrm{Ca}^{2+}$ influx and protein kinase $A$ (PKA) activation, which induces mitochondrial elongation, mitochondrial localization to lipid droplets, lipolysis, $\beta$-oxidation, and UCP1 expression. $\mathrm{Ca}^{2+}$-induced mitochondrial reactive oxygen species activate UCP1. In animals, TRPM8 agonism increases basal metabolic rate, non-shivering thermogenesis, oxygen consumption, exercise endurance, and fatty acid oxidation and decreases abdominal fat percentage. Menthol prevents high-fat diet-induced obesity, glucose intolerance, insulin resistance, and liver triacylglycerol accumulation. Hypothalamic TRPM8 activation releases glucagon, which activates PKA and promotes catabolism. TRPM8 polymorphisms are associated with obesity. In humans, oral menthol and other TRPM8 agonists have little effect. However, topical menthol appears to increase core body temperature and metabolic rate. A randomized clinical control trial of topical menthol in obese patients is warranted.

Key words: Obesity, Weight loss, Mitochondrial uncoupling proteins, Brown adipose tissue, Thermogenesis
Received April 25, 2020

Reviewed May 25, 2020

Accepted June 12, 2020

*Corresponding author

Owen Davis Sanders

https://orcid.org/0000-0003-4093-3166

Department of Biology, Portland State University, 1777 NW 173rd Ave, \#610, Beaverton, OR 97006, USA

Tel: +1-503-809-1333

Fax: +1-503-725-4882

E-mail: owensanders@gmail.com

\section{INTRODUCTION}

Obesity and overweight are two of the most urgently pressing medical challenges facing contemporary healthcare. While the foundational approaches of caloric restriction and exercise focus on reducing energy intake and increasing activity energy expenditure, respectively, modifying resting energy expenditure remains a challenge. One way to do so would be to increase adipose tissue nonshivering thermogenesis. Non-shivering thermogenesis results primarily from expression of uncoupling protein 1 (UCP1), which allows hydrogen ions to be transported down an electrochemical gradient into the mitochondrial matrix without producing adenosine triphosphate, thereby dissipating the energy of the proton mo- tive force as heat. ${ }^{1}$ This uncouples the proton motive force from mitochondrial respiration.

The primary site of thermogenesis is brown adipose tissue, which is rich in iron-containing mitochondria that give rise to its distinct color. Functional brown adipose tissue appears to persist even into adulthood in humans, ${ }^{2,3}$ but its metabolic activity tends to decrease in association with age and obesity. ${ }^{2,4,5}$ In addition, there are distinct subpopulations of "brite" and "beige" adipocytes that are transcriptionally distinct from both classical brown and white adipocytes, and that can be stimulated to attain a brown adipose tissue-like phenotype featuring uncoupled mitochondria. ${ }^{2,6,7}$ It has been reported that human brown adipose tissue is more similar to murine beige adipose tissue than murine brown or white adi-

Copyright (C) 2021 Korean Society for the Study of Obesity

(a) This is an Open Access article distributed under the terms of the Creative Commons Attribution Non-Commercial License (https://creativecommons.org/licenses/by-nc/4.o/) which permits unrestricted non-commercial use, distribution, and reproduction in any medium, provided the original work is properly cited 
pose tissue at the molecular level. ${ }^{6}$

Therapeutically, attempts have been made to stimulate human adipose tissue uncoupling and non-shivering thermogenesis to increase basal energy expenditure. Cold exposure stimulates brown adipose tissue activation in humans. ${ }^{8-12}$ Ice pack application has been shown to beige subcutaneous white adipose tissue and upregulate UCP1 in lean and obese individuals. ${ }^{11}$ Pharmacologically, much of the efforts in this area have focused on $\beta 3$-adrenergic receptors. $\beta 3$-adrenoceptors are activated by norepinephrine, production of which by the sympathetic nervous system is increased by cold and other stressors. Of the $\beta 3$-adrenoceptor agonists tested, ZD7114 and ZD2079, ${ }^{13,14}$ L-796568, ${ }^{14,15}$ and TAK-677 have shown negative results in terms of decreasing adiposity, although TAK677 ( 0.5 mg twice daily) did significantly increase energy expenditure by approximately $13 \mathrm{kcal} /$ day. ${ }^{14,16}$ Mirabegron, by contrast, has shown positive results in human studies on the parameters of adipose tissue beiging ${ }^{11}$ and metabolic activity, ${ }^{17}$ non-esterified fatty acid release, ${ }^{18}$ and basal energy expenditure. ${ }^{17,19}$ This provides proof-of-concept that stimulating adipose tissue through thermogenesis might be a viable complementary strategy to promote weight loss as part of multi-component treatment protocols to combat obesity. However, $\beta 3$-adrenoceptors are not the only receptors activated by cold to induce thermogenesis: transient receptor potential melastatin 8 (TRPM8) channels fulfill both of these criteria as well. ${ }^{2,20-22}$

The TRPM8 channel is the primary cold receptor of the murine peripheral nervous system. ${ }^{20}$ It is activated not only by cold, but also by icilin, ${ }^{23}$ testosterone, ${ }^{24}$ borneol (a traditional Chinese herb and terpene), ${ }^{25}$ and cooling agents (i.e., cold mimetics) such as menthol and eucalyptol. ${ }^{2,20,26-28}$ It is expressed in brown, beige, and white adipocytes, ${ }^{29-31}$ as well as in prostate cells, prostate cancer cells, ${ }^{24}$ dorsal root ganglion sensory neurons, ${ }^{2,24}$ trigeminal ganglia sensory neurons, ${ }^{2} \mathrm{~N} 41$ hypothalamic cells, ${ }^{32}$ and hippocampal neurons. $^{24}$

Emerging evidence has shown that TRPM8 activation leads to protein kinase A (PKA) activation, UCP1 upregulation, increased thermogenesis, and protection from obesity. ${ }^{2,20-22,26,30,33}$ Topical menthol has been shown in rodent models to increase body temperature and non-shivering thermogenesis. ${ }^{26,34,35}$ However, the evidence remains fragmentary, and the plausibility of translating
TRPM8 agonists into clinical applications to treat obesity and overweight status remains unclear. To analyze whether TRPM8 agonism with menthol or other agents may promote clinically relevant weight loss in preclinical animal models and patients who are overweight or obese, we performed a review of TRPM8 agonism focusing on the cold mimetic menthol for treatment of obesity and overweight individuals.

We conducted a literature search in PubMed using the following keywords: “TRPM8 weight loss,” “TRPM8 thermogenesis," “TRPM8 obesity," “TRPM8 overweight," “TRPM8 adipocyte,” "menthol weight loss," "menthol thermogenesis," "menthol obesity," "menthol overweight," and "menthol adipocyte." Results on the association between menthol cigarettes and obesity and other cardiometabolic risk factors ${ }^{36,37}$ were discarded. Studies about menthol in conditions that are not associated with overweight status or obesity (e.g., coli$\mathrm{tis}^{38}$ ) were also discarded. Preclinical, epidemiological, and clinical studies were reviewed.

\section{TRPM8 CHANNELS IN ENERGY HOMEOSTASIS}

Table 1 summarizes the effects induced by the TRPM8 agonists menthol and icilin. In vitro, treating mature adipocytes with $1 \mu \mathrm{M}$ bioavailable menthol for one hour increased RNA expression of genes associated with adipose tissue beiging, namely UCP1, peroxisome proliferator-activated receptor $\gamma$ coactivator $1 \alpha(\mathrm{PGC1} \alpha)$, tumor necrosis factor receptor superfamily member 9, and Homeobox C10. ${ }^{22}$ Menthol was more effective at increasing UCP1 expression and uncoupled respiration in white adipocytes than in brown adipocytes. ${ }^{39}$ In white adipocytes, menthol and icilin significantly increased UCP1 mRNA and protein levels, thermogenesis, glucose uptake, mitochondrial membrane potential, and mitochondrial elongation and clustering around lipid droplets independent of genes involved in mitochondrial biogenesis through TRPM8 activation and consequent $\mathrm{Ca}^{2+}$ influx. ${ }^{29}$ In cultured mouse white adipocytes, menthol significantly increased PGC1 $\alpha$ and UCP1 mRNA levels, effects which were significantly blocked by the PKA inhibitor KT5720 and apparently even more effectively by the cell membrane permeable calcium chelator BAPTA-AM. ${ }^{30}$ Indeed, activation of TRPM8 channels with menthol was found to induce cyto- 
Table 1. The effects induced by menthol and icilin

\begin{tabular}{|c|c|c|}
\hline Drug & Effect & Reference \\
\hline \multirow[t]{22}{*}{ Menthol } & Induces adipose tissue beiging & 22,30 \\
\hline & Upregulates uncoupling protein 1 & $21,22,29,30,40$ \\
\hline & $\begin{array}{l}\text { Upregulates peroxisome proliferator-activated receptor } \gamma \\
\text { coactivator } 1 \alpha\end{array}$ & 30,40 \\
\hline & Increases thermogenesis & $21,29,35,41-43$ \\
\hline & Increases basal energy expenditure & 26,43 \\
\hline & Prevents liver triacylglycerol accumulation & 44 \\
\hline & Prevents insulin resistance & 44 \\
\hline & Improves glucose homeostasis & 21,30 \\
\hline & Increases glucose uptake & 29 \\
\hline & Increases mitochondrial membrane potential & 29 \\
\hline & $\begin{array}{l}\text { Induces mitochondrial elongation and clustering around } \\
\text { lipid droplets }\end{array}$ & 29 \\
\hline & Increases exercise endurance & 40 \\
\hline & Decreases blood lactate and triglyceride levels & 40 \\
\hline & $\begin{array}{l}\text { Increases locomotor activity in normal but not high-fat diet } \\
\text { fed mice }\end{array}$ & 21 \\
\hline & Promotes glucagon release & 44 \\
\hline & Increases oxygen consumption & 35,45 \\
\hline & Decreases the respiratory coefficient & 45 \\
\hline & Increases shivering & 35 \\
\hline & Increases vasoconstriction & 35,43 \\
\hline & Increases heat-seeking behavior & 35 \\
\hline & Prevents weight gain & $21,30,44$ \\
\hline & Decreases abdominal fat percentage & 46 \\
\hline \multirow[t]{7}{*}{ Icilin } & UCP1 upregulation and thermogenesis & 29 \\
\hline & Increases glucose uptake & 29 \\
\hline & Increases mitochondrial membrane potential & 29 \\
\hline & $\begin{array}{l}\text { Induces mitochondrial elongation and clustering around } \\
\text { lipid droplets }\end{array}$ & 29 \\
\hline & Promotes glucagon release & 44 \\
\hline & Increases wet-dog shakes & 47 \\
\hline & $\begin{array}{l}\text { Induces synergistic reversal of diet-induced obesity, } \\
\text { dyslipidemia, and glucose intolerance when combined } \\
\text { with dimethylphenylpiperazinium }\end{array}$ & 33 \\
\hline
\end{tabular}

plasmic $\mathrm{Ca}^{2+}$ influx, $\mathrm{Ca}^{2+}$-dependent PKA phosphorylation, and PKA-dependent UCP1 protein upregulation in adipose tissue, ${ }^{21}$ suggesting that TRPM8 channels activate the PKA/UCP1 pathway. ${ }^{21,48}$

TRPM8 channels may affect energy homeostasis in non-adipose tissues as well. In mice, TRPM8-activated sensory nerves promote brown adipose tissue thermogenesis. ${ }^{49}$ Menthol upregulated UCP1 and PGC1 $\alpha$ mRNA expression in $\mathrm{C} 2 \mathrm{C} 12$ myotubes and mouse skeletal muscle via TRPM8 activation, and dietary menthol increased exercise endurance and decreased blood lactate and triglyceride levels. ${ }^{40}$ Hypothalamic TPRM8 activation appears to pro- mote glucagon release and increased energy expenditure. In mice, acute oral and topical menthol or icilin increased serum glucagon level via TRPM8 activation, and treating mature white 3T3L1 adipocytes with serum from menthol-treated mice increased energy expenditure in a manner that was blocked by a glucagon receptor antagonist. ${ }^{44}$ In N41 hypothalamic cells, TRPM8 activation mediated the effects on $\mathrm{Ca}^{2+}$ currents of the thyroid hormone metabolite 3-iodothyronamine, ${ }^{32}$ central intracerebroventricular administration of which increased glucagon and endogenous glucose production. ${ }^{50}$ Glucagon has an acute hyperglycemic effect but also increases energy expenditure and decreases food intake in rodents when co-administered with glucagon-like peptide-1. ${ }^{51,52}$

In vivo, TRPM8 knockout mice had attenuated $\mathrm{UCP} 1$ protein expression in their brown adipose tissue. ${ }^{53}$ TRPM8 inhibition decreased deep body temperature in mice and rats. ${ }^{54}$ TRPM8 knockout mice displayed hypothermia, hyperphagia, decreased fat oxidation, and obesity. ${ }^{55}$ Even in thermoneutral conditions, TRPM8 activation by topical menthol application increased oxygen consumption and decreased the respiratory coefficient, suggesting that TRPM8 activation may promote fat oxidation. ${ }^{45}$ TRPM8 agonism with intragastric menthol or 1,8-cineole increased thermogenesis in mice. ${ }^{41}$ Topical menthol increased core body temperature, shivering, oxygen consumption, tail skin vasoconstriction, and heatseeking behavior in mice. ${ }^{35}$ Intraperitoneal injection of icilin increased wet-dog shakes in mice, ${ }^{47}$ and dietary menthol increased locomotor activity in wild-type mice but not those fed a high-fat diet even though it increased thermogenesis in both. ${ }^{21}$ These findings suggest that TRPM8 activation can increase energy expenditure both by increasing locomotor activity and independent of activity level through non-shivering thermogenesis.

Topical menthol significantly increased basal metabolic rate despite unchanged food intake in a murine model of diet-induced obesity. ${ }^{26}$ Dietary menthol treatment attenuated high-fat diet-induced obesity and improved glucose homeostasis and white adipose tissue beiging in a rodent model. ${ }^{30}$ Via the TRPM8/ $\mathrm{Ca}^{2+} /$ PKA/UCP1 pathway, dietary menthol prevented diet-induced obesity and glucose intolerance in mice. ${ }^{21}$ In broiler chickens, supplemental peppermint leaves or menthol increased body weight and dietary intake, decreased the percentage of breast and leg muscle lost due to cooking, and decreased abdominal fat percentage. ${ }^{46}$ 
Interestingly, menthol or peppermint was also associated with decreased mortality in these birds. ${ }^{46}$ Chronic oral (50 and $100 \mathrm{mg}$ / $\mathrm{kg} /$ day for 12 weeks) or topical menthol in high-fat diet fed mice prevented weight gain and adipose tissue hypertrophy, as well as liver triacylglycerol accumulation and insulin resistance. ${ }^{44}$ Combining subcutaneously injected icilin and dimethylphenylpiperazinium to target the appetite-suppressing nicotinic acetylcholine receptor $\alpha 3 \beta 4$ resulted in synergistic reversal of diet-induced obesity, dyslipidemia, and glucose intolerance. ${ }^{33}$

Recently, Sakellariou et al. ${ }^{2}$ proposed that chronic administration of oral menthol to obese individuals may induce sustained weight loss by increasing adipose tissue thermogenesis. The TRPM 8 gene has been found to be differentially expressed in two individuals with familial obesity and one non-obese individual from the same Thai family. Furthermore, its minor allele frequency was low, indicating a possible causal variant. ${ }^{56}$ In a Turkish population, the rs12472151 polymorphism of the TRPM8 gene was associated with metabolic syndrome. ${ }^{57}$

In 16-18 healthy adult individuals, oral administration of $0.2 \mathrm{~mL}$ of a TRPM8 agonist cooling flavor in $200 \mathrm{~mL}$ tomato juice did not alter energy expenditure or substrate utilization. ${ }^{58}$ However, in seven swimmers and seven physical education students, topical menthol decreased rectal temperature loss caused by immersion in cold water, suggesting that topical menthol may have increased thermogenesis. $^{42}$ In 20 healthy adult individuals, topical menthol significantly increased metabolic rate (18\%), cutaneous vasoconstriction, body heat storage, and rectal temperature compared to control and oral menthol. ${ }^{43}$ Oral menthol underperformed relative to topical menthol due in part to increased glucuronidation and elimination of oral menthol compared to topical menthol. ${ }^{43}$

\section{CONCLUSION}

Overall, the few associated studies performed in human participants suggest that topical menthol might effectively promote increased basal energy expenditure and weight loss through nonshivering thermogenesis, whereas oral TRPM8 agonists (at least at the low doses used in these studies) may not. ${ }^{42,43,58}$ One explanation for this difference is that oral menthol is more readily glucuronidated and excreted than topical menthol. ${ }^{43}$ However, a complementa- ry explanation is that topical menthol may reach the target adipose tissue more directly and thereby achieve greater concentrations there than oral menthol. Therefore, future studies in human participants should study the effects of topical menthol or icilin, as topical administration is the most promising drug delivery method.

Another conclusion that can be drawn from this review is that there is a TRPM8/ $\mathrm{Ca}^{2+} / \mathrm{PKA} / \mathrm{UCP} 1$ pathway whose activation uncouples respiration and increases non-shivering thermogenesis, and it is active and physiologically relevant in adipose tissue, especially in white adipose tissue (Fig. 1). ${ }^{21,22,29,39,48}$ The pleiotropic effects of PKA activation in this context, however, warrant further mechanistic discussion to glean additional therapeutic insights. Previously, PKA activation has been shown to promote lipolysis ${ }^{59,60}$ and $\beta$-oxidation. ${ }^{61}$ In one of the studies reviewed, menthol or icilin was found to not only upregulate UCP1, but also to induce mito-

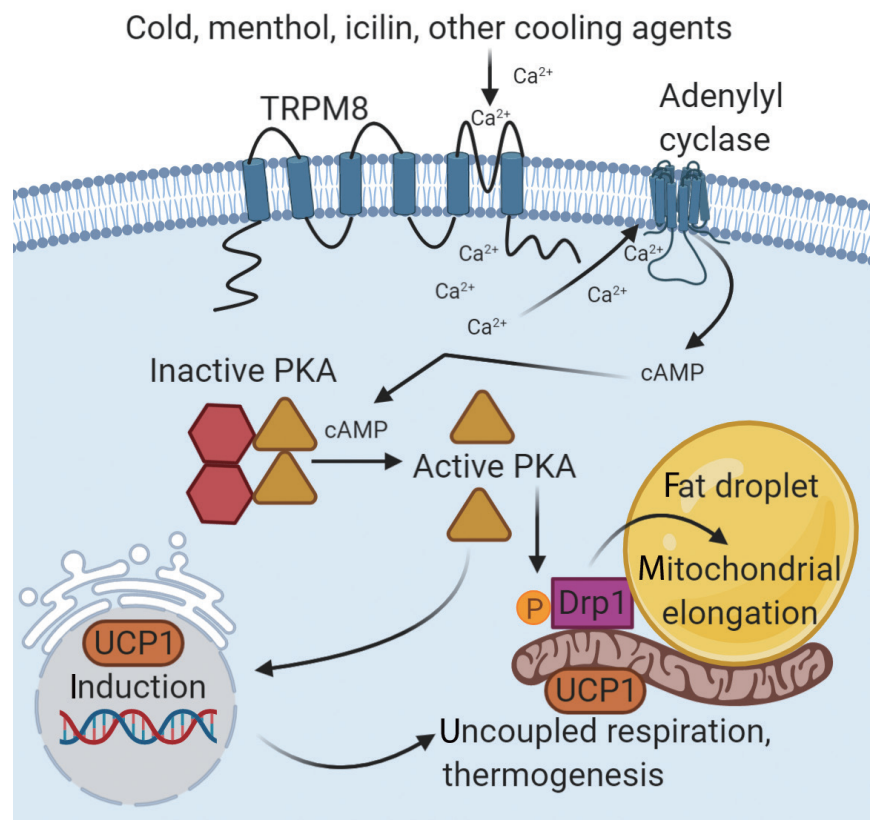

Figure 1. Mechanisms of transient receptor potential melastatin 8 (TRPM8)-mediated uncoupled respiration and mitochondrial elongation. Cold, menthol, icilin, and other cooling agents open brown, beige, and white adipocyte TRPM8 channels. ${ }^{2,20,31,23-30}$ Extracellular $\mathrm{Ca}^{2+}$ ions influx through TRPM8 channels into the adipocyte cytoplasm. ${ }^{29}$ Peri-plasma membrane $\mathrm{Ca}^{2+}$ activates adenylyl cyclase 1 and 8 , which generate cyclic adenosine monophosphate (cAMP). ${ }^{62}$ cAMP activates protein kinase $A$ (PKA) to induce uncoupling protein 1 (UCP1) transcription. 2,20-22,26,30,33 Once translated, UCP1 proteins are imported into mitochondria and localized to the inner mitochondrial membrane, where they allow protons to diffuse down an electrochemical gradient into the mitochondrial matrix, dissipating the energy of the proton motive force as heat instead of generating adenosine triphosphate.' PKA also phosphorylates and thereby activates dynamin-related protein 1 (Drp1), which induces mitochondrial fusion and elongation around lipid droplets. ${ }^{29,63}$ 
chondrial elongation and localization around lipid droplets via TRPM8 activation and $\mathrm{Ca}^{2+}$ influx. ${ }^{29}$ This probably occurred via PKA activation and PKA phosphorylation of dynamin-related protein 1 (Drp1). ${ }^{63}$ Drp 1 is a large GTPase that executes mitochondrial fission, whereby mitochondria split to form two daughter mitochondria. PKA activation inhibits Drp1, promoting mitochondrial fusion and elongation (Fig. 1). ${ }^{63}$

TRPM8 activation transduces its signal into the cell via $\mathrm{Ca}^{2+}$ influx and raises the mitochondrial membrane potential, making it more positive and promoting depolarization. This result is intriguing $^{29}$ since cytoplasmic $\mathrm{Ca}^{2+}$ becomes sequestered in the mitochondria, dissipating the mitochondrial membrane potential, ${ }^{64}$ increasing mitochondrial reactive oxygen species (ROS) production, ${ }^{65}$ and eventually promoting permeability transition opening and cell death. ${ }^{64}$ Therefore, it appears that TRPM8 activation may lead to mild, physiological mitochondrial $\mathrm{Ca}^{2+}$ accumulation. This would explain the more positive mitochondrial membrane potential, and it would also predict that TRPM8 activation should lead to mitochondrial ROS production. Consistent with this relationship, interscapular brown adipose tissue activation in mice increased mitochondrial ROS production in this tissue. ${ }^{66}$ Furthermore, ROS were found to activate UCP1 by sulfenylating its Cys 253 residue. ${ }^{66}$ Moreover, experiments with antioxidants showed that mitochondrial ROS are required to prevent hypothermia and to increase energy expenditure upon cold exposure. ${ }^{66}$ Therefore, antioxidants might be contraindicated while administering topical menthol to ensure its efficacy, although further experiments are required to evaluate this possibility.

The connection between hypothalamic TRPM8 signaling and glucagon production ${ }^{32,44}$ is also intriguing, since cold exposure acutely raises glucagon level, ${ }^{67}$ and both TRPM8 channels and glucagon increase PKA activity. ${ }^{21,68}$ This makes it appear as if glucagon were a hormone messenger of TRPM8 agonism, with both signals converging on PKA activation and PKA-driven catabolism.

Therefore, this literature review concludes that menthol should be studied further in patients to test whether it can deliver clinicallyrelevant increases in non-shivering thermogenesis, basal energy expenditure, and weight loss. ${ }^{42,43,58}$ Menthol raises the basal metabolic rate by activating the TRPM8/Ca ${ }^{2+} / \mathrm{PKA}, \mathrm{PKA} / \mathrm{UCP} 1$, and PKA/ Drp1 pathways in white adipose tissue, resulting in beiging. ${ }^{21,22,29,30,48}$
Cold, menthol, and glucagon promote catabolism via PKA activation. ${ }^{21,32,44,67,68} \mathrm{~A}$ clinical trial of menthol for weight loss in obese patients is warranted. ${ }^{42,43,58,66}$

\section{CONFLICTS OF INTEREST}

The authors declare no conflict of interest.

\section{AUTHOR CONTRIBUTIONS}

Study concept and design, drafting of the manuscript, and critical revision of the manuscript: all authors.

\section{REFERENCES}

1. Klingenberg M, Huang SG. Structure and function of the uncoupling protein from brown adipose tissue. Biochim Biophys Acta 1999;1415:271-96.

2. Sakellariou P, Valente A, Carrillo AE, Metsios GS, Nadolnik L, Jamurtas AZ, et al. Chronic l-menthol-induced browning of white adipose tissue hypothesis: a putative therapeutic regime for combating obesity and improving metabolic health. Med Hypotheses 2016;93:21-6.

3. Nedergaard J, Bengtsson T, Cannon B. Unexpected evidence for active brown adipose tissue in adult humans. Am J Physiol Endocrinol Metab 2007;293:E444-52.

4. Pfannenberg C, Werner MK, Ripkens S, Stef I, Deckert A, Schmadl M, et al. Impact of age on the relationships of brown adipose tissue with sex and adiposity in humans. Diabetes 2010; 59:1789-93.

5. Virtanen KA, Nuutila P. Brown adipose tissue in humans. Curr Opin Lipidol 2011;22:49-54.

6. Wu J, Boström P, Sparks LM, Ye L, Choi JH, Giang AH, et al. Beige adipocytes are a distinct type of thermogenic fat cell in mouse and human. Cell 2012;150:366-76.

7. Petrovic N, Walden TB, Shabalina IG, Timmons JA, Cannon B, Nedergaard J. Chronic peroxisome proliferator-activated receptor gamma (PPARgamma) activation of epididymally derived white adipocyte cultures reveals a population of thermogenically competent, UCP1-containing adipocytes molec- 
ularly distinct from classic brown adipocytes. J Biol Chem 2010; 285:7153-64.

8. van Marken Lichtenbelt WD, Vanhommerig JW, Smulders NM, Drossaerts JM, Kemerink GJ, Bouvy ND, et al. Cold-activated brown adipose tissue in healthy men. N Engl J Med 2009;360: 1500-8.

9. Hanssen MJ, van der Lans AA, Brans B, Hoeks J, Jardon KM, Schaart G, et al. Short-term cold acclimation recruits brown adipose tissue in obese humans. Diabetes 2016;65:1179-89.

10. van der Lans AA, Wierts R, Vosselman MJ, Schrauwen P, Brans B, van Marken Lichtenbelt WD. Cold-activated brown adipose tissue in human adults: methodological issues. Am J Physiol Regul Integr Comp Physiol 2014;307:R103-13.

11. Finlin BS, Memetimin H, Confides AL, Kasza I, Zhu B, Vekaria $\mathrm{HJ}$, et al. Human adipose beiging in response to cold and mirabegron. JCI Insight 2018;3:e121510.

12. Wijers SL, Saris WH, van Marken Lichtenbelt WD. Cold-induced adaptive thermogenesis in lean and obese. Obesity (Silver Spring) 2010;18:1092-9.

13. Buemann B, Toubro S, Astrup A. Effects of the two beta3-agonists, ZD7114 and ZD2079 on 24 hour energy expenditure and respiratory quotient in obese subjects. Int J Obes Relat Metab Disord 2000;24:1553-60.

14. Mukherjee J, Baranwal A, Schade KN. Classification of therapeutic and experimental drugs for brown adipose tissue activation: potential treatment strategies for diabetes and obesity. Curr Diabetes Rev 2016;12:414-28.

15. Larsen TM, Toubro S, van Baak MA, Gottesdiener KM, Larson P, Saris WH, et al. Effect of a 28-d treatment with L-796568, a novel beta(3)-adrenergic receptor agonist, on energy expenditure and body composition in obese men. Am J Clin Nutr 2002;76:780-8.

16. Redman LM, de Jonge L, Fang X, Gamlin B, Recker D, Greenway FL, et al. Lack of an effect of a novel beta3-adrenoceptor agonist, TAK-677, on energy metabolism in obese individuals: a double-blind, placebo-controlled randomized study. J Clin Endocrinol Metab 2007;92:527-31.

17. Cypess AM, Weiner LS, Roberts-Toler C, Franquet Elía E, Kessler SH, Kahn PA, et al. Activation of human brown adipose tissue by a $\beta 3$-adrenergic receptor agonist. Cell Metab
2015;21:33-8.

18. Baskin AS, Linderman JD, Brychta RJ, McGehee S, AnflickChames E, Cero C, et al. Regulation of human adipose tissue activation, gallbladder size, and bile acid metabolism by a $\beta 3$ adrenergic receptor agonist. Diabetes 2018;67:2113-25.

19. Loh RK, Formosa MF, La Gerche A, Reutens AT, Kingwell BA, Carey AL. Acute metabolic and cardiovascular effects of mirabegron in healthy individuals. Diabetes Obes Metab 2019; 21:276-84.

20. Bautista DM, Siemens J, Glazer JM, Tsuruda PR, Basbaum AI, Stucky CL, et al. The menthol receptor TRPM8 is the principal detector of environmental cold. Nature 2007;448:204-8.

21. Ma S, Yu H, Zhao Z, Luo Z, Chen J, Ni Y, et al. Activation of the cold-sensing TRPM8 channel triggers UCP1-dependent thermogenesis and prevents obesity. J Mol Cell Biol 2012;4: 88-96.

22. Khare P, Chauhan A, Kumar V, Kaur J, Mahajan N, Kumar V, et al. Bioavailable menthol (transient receptor potential melastatin-8 agonist) induces energy expending phenotype in differentiating adipocytes. Cells 2019;8:383.

23. Wei ET, Seid DA. AG-3-5: a chemical producing sensations of cold. J Pharm Pharmacol 1983;35:110-2.

24. Asuthkar S, Demirkhanyan L, Sun X, Elustondo PA, Krishnan $\mathrm{V}$, Baskaran P, et al. The TRPM8 protein is a testosterone receptor. II. Functional evidence for an ionotropic effect of testosterone on TRPM8. J Biol Chem 2015;290:2670-88.

25. Nuutinen T. Medicinal properties of terpenes found in Cannabis sativa and Humulus lupulus. Eur J Med Chem 2018;157: 198-228.

26. Vizin RC, Motzko-Soares AC, Armentano GM, Ishikawa DT, Cruz-Neto AP, Carrettiero DC, et al. Short-term menthol treatment promotes persistent thermogenesis without induction of compensatory food consumption in Wistar rats: implications for obesity control. J Appl Physiol (1985) 2018;124: 672-83.

27. Paschke M, Tkachenko A, Ackermann K, Hutzler C, Henkler F, Luch A. Activation of the cold-receptor TRPM8 by low levels of menthol in tobacco products. Toxicol Lett 2017;271: 50-7.

28. McKemy DD. TRPM8: the cold and menthol receptor. In: 
Liedtke WB, Heller S, editors. TRP ion channel function in sensory transduction and cellular signaling cascades. Boca Raton (FL): CRC Press/Taylor \& Francis; 2007.

29. Rossato M, Granzotto M, Macchi V, Porzionato A, Petrelli L, Calcagno A, et al. Human white adipocytes express the cold receptor TRPM8 which activation induces UCP1 expression, mitochondrial activation and heat production. Mol Cell Endocrinol 2014;383:137-46.

30. Jiang C, Zhai M, Yan D, Li D, Li C, Zhang Y, et al. Dietary menthol-induced TRPM8 activation enhances WAT "browning" and ameliorates diet-induced obesity. Oncotarget 2017;8: 75114-26.

31. Bishnoi M, Kondepudi KK, Gupta A, Karmase A, Boparai RK. Expression of multiple transient receptor potential channel genes in murine 3T3-L1 cell lines and adipose tissue. Pharmacol Rep 2013;65:751-5.

32. Bräunig J, Mergler S, Jyrch S, Hoefig CS, Rosowski M, Mittag J, et al. 3-Iodothyronamine activates a set of membrane proteins in murine hypothalamic cell lines. Front Endocrinol (Lausanne) 2018;9:523.

33. Clemmensen C, Jall S, Kleinert M, Quarta C, Gruber T, Reber J, et al. Coordinated targeting of cold and nicotinic receptors synergistically improves obesity and type 2 diabetes. Nat Commun 2018;9:4304.

34. El Hadi H, Di Vincenzo A, Vettor R, Rossato M. Food ingredients involved in white-to-brown adipose tissue conversion and in calorie burning. Front Physiol 2019;9:1954.

35. Tajino K, Matsumura K, Kosada K, Shibakusa T, Inoue K, Fushiki T, et al. Application of menthol to the skin of whole trunk in mice induces autonomic and behavioral heat-gain responses. Am J Physiol Regul Integr Comp Physiol 2007;293: R2128-35.

36. Antonio AM, Fagan P, Hamamura FD, Lagua IJ, Liu J, Park DJ, et al. Menthol cigarette smoking and obesity in young adult daily smokers in Hawaii. Prev Med Rep 2015;2:946-52.

37. Míguez-Burbano MJ, Vargas M, Quiros C, Lewis JE, Espinoza L, Deshratan A. Menthol cigarettes and the cardiovascular risks of people living with HIV. J Assoc Nurses AIDS Care 2014;25:427-35.

38. Ghasemi-Pirbaluti M, Motaghi E, Bozorgi H. The effect of menthol on acute experimental colitis in rats. Eur J Pharmacol 2017;805:101-7.

39. Goralczyk A, van Vijven M, Koch M, Badowski C, Yassin MS, Toh SA, et al. TRP channels in brown and white adipogenesis from human progenitors: new therapeutic targets and the caveats associated with the common antibiotic, streptomycin. FASEB J 2017;31:3251-66.

40. Li C, Li J, Xiong X, Liu Y, Lv Y, Qin S, et al. TRPM8 activation improves energy expenditure in skeletal muscle and exercise endurance in mice. Gene 2018;641:111-6.

41. Masamoto Y, Kawabata F, Fushiki T. Intragastric administration of TRPV1, TRPV3, TRPM8, and TRPA1 agonists modulates autonomic thermoregulation in different manners in mice. Biosci Biotechnol Biochem 2009;73:1021-7.

42. Botonis PG, Geladas ND, Kounalakis SN, Cherouveim ED, Koskolou MD. Effects of menthol application on the skin during prolonged immersion in swimmers and controls. Scand J Med Sci Sports 2017;27:1560-8.

43. Valente A, Carrillo AE, Tzatzarakis MN, Vakonaki E, Tsatsakis AM, Kenny GP, et al. The absorption and metabolism of a single L-menthol oral versus skin administration: Effects on thermogenesis and metabolic rate. Food Chem Toxicol 2015; 86:262-73.

44. Khare P, Mangal P, Baboota RK, Jagtap S, Kumar V, Singh DP, et al. Involvement of glucagon in preventive effect of menthol against high fat diet induced obesity in mice. Front Pharmacol 2018;9:1244.

45. Kozyreva TV, Kozaruk VP, Tkachenko EY, Khramova GM. Effect of TRPM8 ion channel activation on thermoregulatory response to cooling. Ross Fiziol Zh Im I M Sechenova 2011; 97:218-26.

46. Abdel-Wareth AA, Kehraus S, Südekum KH. Peppermint and its respective active component in diets of broiler chickens: growth performance, viability, economics, meat physicochemical properties, and carcass characteristics. Poult Sci 2019;98: 3850-9.

47. Rossi HL, Vierck CJ Jr, Caudle RM, Yezierski RP, Neubert JK. Dose-dependent effects of icilin on thermal preference in the hindpaw and face of rats. J Pain 2009;10:646-53.

48. Dickson LM, Gandhi S, Layden BT, Cohen RN, Wicksteed B. 
Protein kinase A induces UCP1 expression in specific adipose depots to increase energy expenditure and improve metabolic health. Am J Physiol Regul Integr Comp Physiol 2016;311: R79-88.

49. Uchida K, Dezaki K, Yoneshiro T, Watanabe T, Yamazaki J, Saito M, et al. Involvement of thermosensitive TRP channels in energy metabolism. J Physiol Sci 2017;67:549-60.

50. Klieverik LP, Foppen E, Ackermans MT, Serlie MJ, Sauerwein HP, Scanlan TS, et al. Central effects of thyronamines on glucose metabolism in rats. J Endocrinol 2009;201:377-86.

51. Scott RV, Bloom SR. Problem or solution: the strange story of glucagon. Peptides 2018;100:36-41.

52. Parker JA, McCullough KA, Field BC, Minnion JS, Martin NM, Ghatei MA, et al. Glucagon and GLP-1 inhibit food intake and increase $\mathrm{c}$-fos expression in similar appetite regulating centres in the brainstem and amygdala. Int J Obes (Lond) 2013;37:1391-8.

53. Moraes MN, de Assis LV, Henriques FD, Batista ML Jr, Güler $\mathrm{AD}$, Castrucci AM. Cold-sensing TRPM8 channel participates in circadian control of the brown adipose tissue. Biochim Biophys Acta Mol Cell Res 2017;1864:2415-27.

54. Almeida MC, Hew-Butler T, Soriano RN, Rao S, Wang W, Wang J, et al. Pharmacological blockade of the cold receptor TRPM8 attenuates autonomic and behavioral cold defenses and decreases deep body temperature. J Neurosci 2012;32: 2086-99.

55. Reimúndez A, Fernández-Peña C, García G, Fernández R, Ordás P, Gallego R, et al. Deletion of the cold thermoreceptor TRPM8 increases heat loss and food intake leading to reduced body temperature and obesity in mice. J Neurosci 2018;38: 3643-56.

56. Kaewsutthi S, Santiprabhob J, Phonrat B, Tungtrongchitr A, Lertrit P, Tungtrongchitr R. Exome sequencing in Thai patients with familial obesity. Genet Mol Res 2016;15:gmr8311.

57. Tabur S, Oztuzcu S, Duzen IV, Eraydin A, Eroglu S, Ozkaya M, et al. Role of the transient receptor potential (TRP) channel gene expressions and TRP melastatin (TRPM) channel gene polymorphisms in obesity-related metabolic syndrome. Eur Rev Med Pharmacol Sci 2015;19:1388-97.

58. Michlig S, Merlini JM, Beaumont M, Ledda M, Tavenard A,
Mukherjee R, et al. Effects of TRP channel agonist ingestion on metabolism and autonomic nervous system in a randomized clinical trial of healthy subjects. Sci Rep 2016;6:20795.

59. Larsson S, Jones HA, Göransson O, Degerman E, Holm C. Parathyroid hormone induces adipocyte lipolysis via PKAmediated phosphorylation of hormone-sensitive lipase. Cell Signal 2016;28:204-13.

60. Duncan RE, Ahmadian M, Jaworski K, Sarkadi-Nagy E, Sul HS. Regulation of lipolysis in adipocytes. Annu Rev Nutr 2007; 27:79-101.

61. Gerhart-Hines Z, Dominy JE Jr, Blättler SM, Jedrychowski MP, Banks AS, Lim JH, et al. The cAMP/PKA pathway rapidly activates SIRT1 to promote fatty acid oxidation independently of changes in NAD(+). Mol Cell 2011;44:851-63.

62. Hofer AM. Interactions between calcium and cAMP signaling. Curr Med Chem 2012;19:5768-73.

63. Loh JK, Lin CC, Yang MC, Chou CH, Chen WS, Hong MC, et al. GSKIP- and GSK3-mediated anchoring strengthens cAMP/PKA/Drp1 axis signaling in the regulation of mitochondrial elongation. Biochim Biophys Acta 2015;1853:1796807.

64. McKenzie M, Lim SC, Duchen MR. Simultaneous measurement of mitochondrial calcium and mitochondrial membrane potential in live cells by fluorescent microscopy. J Vis Exp 2017; (119):55166.

65. Adam-Vizi V, Starkov AA. Calcium and mitochondrial reactive oxygen species generation: how to read the facts. J Alzheimers Dis 2010;20 Suppl 2(Suppl 2):S413-26.

66. Chouchani ET, Kazak L, Jedrychowski MP, Lu GZ, Erickson BK, Szpyt J, et al. Mitochondrial ROS regulate thermogenic energy expenditure and sulfenylation of UCP1. Nature 2016; 532:112-6.

67. Seitz HJ, Krone W, Wilke H, Tarnowski W. Rapid rise in plasma glucagon induced by acute cold exposure in man and rat. Pflugers Arch 1981;389:115-20.

68. Dalle S, Longuet C, Costes S, Broca C, Faruque O, Fontés G, et al. Glucagon promotes cAMP-response element-binding protein phosphorylation via activation of ERK1/2 in MIN6 cell line and isolated islets of Langerhans. J Biol Chem 2004; 279:20345-55. 